\title{
Economical Efficiency of Combined Cooling Heating and Power Systems Based on an Enthalpy Method
}

\author{
Yan $\mathrm{Xu}{ }^{1}$, Wenyu $\mathrm{Li}^{2}$ and Jiahai Yuan ${ }^{2, *}$ \\ 1 School of Management Science and Engineering, Shanxi University of Finance and Economics, \\ Shanxi 030006, China; xuyan@sxufe.edu.cn \\ 2 School of Economics and Management, North China Electric Power University, Beijing 102206, China; \\ liwenyuncepu@163.com \\ * Correspondence: yuanjiahai@ncepu.edu.cn; Tel.: +86-010-6177-3091
}

Received: 22 September 2017; Accepted: 6 November 2017; Published: 9 November 2017

\begin{abstract}
As the living standards of Chinese people have been improving, the energy demand for cooling and heating, mainly in the form of electricity, has also expanded. Since an integrated cooling, heating and power supply system (CCHP) will serve this demand better, the government is now attaching more importance to the application of CCHP energy systems. Based on the characteristics of the combined cooling heating and power supply system, and the method of levelized cost of energy, two calculation methods for the evaluation of the economical efficiency of the system are employed when the energy production in the system is dealt with from the perspective of exergy. According to the first method, fuel costs account for about $75 \%$ of the total cost. In the second method, the profits from heating and cooling are converted to fuel costs, resulting in a significant reduction of fuel costs, accounting for $60 \%$ of the total cost. Then the heating and cooling parameters of gas turbine exhaust, heat recovery boiler, lithium-bromide heat-cooler and commercial tariff of provincial capitals were set as benchmark based on geographic differences among provinces, and the economical efficiency of combined cooling heating and power systems in each province were evaluated. The results shows that the combined cooling heating and power system is economical in the developed areas of central and eastern China, especially in Hubei and Zhejiang provinces, while in other regions it is not. The sensitivity analysis was also made on related influencing factors of fuel cost, demand intensity in heating and cooling energy, and bank loans ratio. The analysis shows that the levelized cost of energy of combined cooling heating and power systems is very sensitive to exergy consumption and fuel costs. When the consumption of heating and cooling energy increases, the unit cost decreases by 0.1 yuan $/ \mathrm{kWh}$, and when the on-grid power ratio decreases by $20 \%$, the cost may increase by 0.1 yuan $/ \mathrm{kWh}$. Finally, some suggestions were offered from the perspective of the power grid, gas sector reform, heating and cooling systems and other aspects to promote the use of combined cooling heating and power systems in the future.
\end{abstract}

Keywords: combined cooling heating and power; economical efficiency; enthalpy method; levelized cost of energy; China

\section{Introduction}

Since the economic and energy structures have been continuously improved, and the energy consumption structures have kept changing in various countries, abundant studies have been done on the centralized power generation taking natural gas as the fuel [1] and the distributed energy sources system. Distributed energy sources are valued by many countries for their unique advantages [2]. Scholars from different countries have done a great deal of research based on the economic and energy environment of their own countries. A Combined Cooling, Heating and Power (CCHP) energy system possesses excellent adaptability, since it does not impose high requirements on heat source varieties 
and can be operated with biofuels [3,4], as well as wind power and photovoltaic power [5,6]. Abundant studies can be found in CCHP energy systems using gas turbines as their driving force [7-9].

A Combined Cooling, Heating and Power (CCHP) system is a new type of energy system built at the user location or nearby. It is based on the concept of energy cascade utilization, which integrates refrigeration, heating and power generation [10]. Compared with other distributed energy forms, CCHP systems are mature and widely used internationally, and they are the main direction of China's distributed energy development.

CCHP systems achieves the cascade utilization of the heat after the combustion of natural gas. High-grade heat moves the gas turbine to generate electricity, and then uses the exhaust heat in the gas turbine to provide refrigeration and heating. The cold and heat energy are directly supplied to the nearest demand, producing the economic benefits. The CCHP system can be operated independently or in multiple units to cope with user demand under different power loads. CCHP systems can have energy efficiencies of up to $80 \%$ [11] due to the lack of long-distance transmission losses and the full utilization of thermal energy. Moreover, CCHP systems play an important role in energy conservation and emission reduction with the function of load shifting on power grids and natural gas pipeline networks. They can not only enhance the safety of the energy supply, but also save social public costs [12].

As early as in 2000, the former State Development Planning Commission together with other four ministries issued the notice on the Development of Combined Heat and Power (CHP), and encouraged the CHP development in relatively decentralized public buildings [13]. In the following years, the National Development and Reform Commission (NDRC), the Ministry of Finance (MOF), Housing and Urban-Rural Development (MOHURD), the National Energy Administration (NEA), the State Grid Corporation of China (SGCC) and other relevant units have jointly or independently introduced the policies to promote CCHP energy systems. In August 2010, the MOHURD issued a technical regulation for the development and construction of CCHP systems [14]. NDRC, NEA and MOHURD jointly issued the "The Implementation Rules of Natural Gas Distributed Energy Demonstration Project" to provide relevant incentives and preferential policies for demonstration projects. Although there is strong policy support, CCHP systems are currently not widely applied in China [15].

Theoretical studies of exergy analysis and thermoeconomics in China started very early and have been applied to a certain degree. The thermoeconomics model and the exergy cost model for the plant based on the Fuel-Product concept have been defined to quantify the productive interaction between different devices [16]. By using a simulator, Structural Theory is a powerful and effective tool, and it can make up the insufficiencies of the conventional thermodynamic methods and can be used for the cost-effective operation analysis and optimization in thermal power plants and other complex energy systems [17]. Based on the exergy balance equations, a general matrix equation for regenerative systems of fossil fired power sets has been deduced. These equations may also serve as the basis for constructing relevant general exergy analysis models of exergy distribution not only of regenerative systems, but also of whole power sets [18]. A cost analysis method based on thermoeconomics was applied to a 300-MW pulverized coal fired power plant. The results show that the specific irreversibility cost is more suitable than the unit exergy cost of product in quantifying and representing the production performance of a component [19]. Thermo-economic structural theory was used to analyze two modes of a solar-aided power generation system. The power output is $57.2 \mathrm{MW}$ higher in power-boosting mode and the thermo-economic cost of solar energy was found to be very high because of this large investment [20].

For the technical-economic feasibility of various heating and/or cooling systems, a comparative analysis of various heating systems for residential buildings in a Mediterranean climate by using the equipment's efficiency and the lifecycle cost as criteria has shown in [21]. The Energy Hub methodology is presented and used as tool for evaluating energy consumption. The results obtained are useful to identify benefits that might be obtained by the CHP system, depending on its regulation 
and on the economic variables [22]. For the limited existing projects and industry experience of CCHP distributed energy systema, it needs to establish the economic evaluation model based on the second law of thermodynamics [23]. For CCHP systema based on micro-gas turbines, the economic optimization model with an objective function of minimizing the cost was developed. A variety of contributing factors such as load ratio differences, and fuel costs are incorporated to show their influences on systems economics [24]. The building of CCHP systems has no economic benefit under the existing price system and the economic benefits are getting worse with the rising price of gas [25]. A combination of exergy analysis and life cycle assessment (LCA) was presented to show the comparative exergoenvironmental analysis and assessment of various residential heating systems [26]. From the above analysis, most scholars have evaluated the economy of heating and/or cooling systems for specific cases. Since the energy system has different operating environments and loads in different regions, this kind of discussion has certain limitations. According to the definition of exergy [27], in this paper, the steam generated after high temperature flue gas from gas turbine enters the heat recovery boiler directly goes through the heating and meanwhile, each part was calculated based on energy balance rather than heat exchange calculation. Then two methods (energy equivalent and economic value equivalent) based on the Levelized Cost of Energy (LCOE) are employed in the paper to evaluate the economical efficiency of a CCHP system.

The remainder of the paper will be organized as follows: Section 2 provides an analysis framework. Section 3 presents two evaluation methods for CCHP system and their comparison. Section 4 presents the sensitivity analysis and Section 5 concludes the paper and provides the policy suggestions.

\section{Analysis Framework}

In order to evaluate the economical efficiency of the CCHP system, this paper takes exergy into consideration and calculates the energy that can be sold according to the enthalpy change when the working fluids go through each part of the energy system. Moreover, the economical evaluation of the supposed system is also examined based on the LCOE, a widely applied method to determine the economical efficiency of energy [28-30].

In this paper, a 16.6 MW gas turbine was taken as an example to introduce the method of economical efficiency evaluation, because gas turbine manufacturers are protective of the performance parameters of their systems, but in this case the data are mostly available. The selection of a $16.6 \mathrm{MW}$ turbine is only a demonstration example of the proposed methodology. If necessary and with available data, the economy of other capacity systems can also be calculated by this method.

Due to the external environment constraints in commercial operation, the case of second entry of steam into the gas turbine was not taken into consideration. In order to analyze the economical efficiency of the CCHP energy system, two processes were adopted for mutual verification. In the first process, heating and cooling output of CCHP energy system is converted to electric energy based on kilowatts of energy, then the kilowatt cost is calculated based on the LCOE. In the second process, according to market price, the heating and cooling energy is converted to income to compensate for some costs; then the LCOE of electricity produced by the CCHP energy system is calculated.

\subsection{Flowing Path of Working Fluids in the CCHP Energy System}

There are multiple kinds of CCHP combinations. In this study, the mode of prime mover + heat recovery boiler + absorption-type water chiller-heater unit was adopted. The flow of the working fluids is shown in Figure 1.

The enthalpy calculation starts from the exhaust of the gas turbine. Since the enthalpy declines and the working fluid changes as it flow through different apparatus, the energy loss is calculated by the stages. The exergy for the use of consumers is then calculated and converted to equivalent electricity in relation to the cooling and heating COP parameters of the electric compressor. Based on such calculations, the economical efficiency is therefore evaluated. 


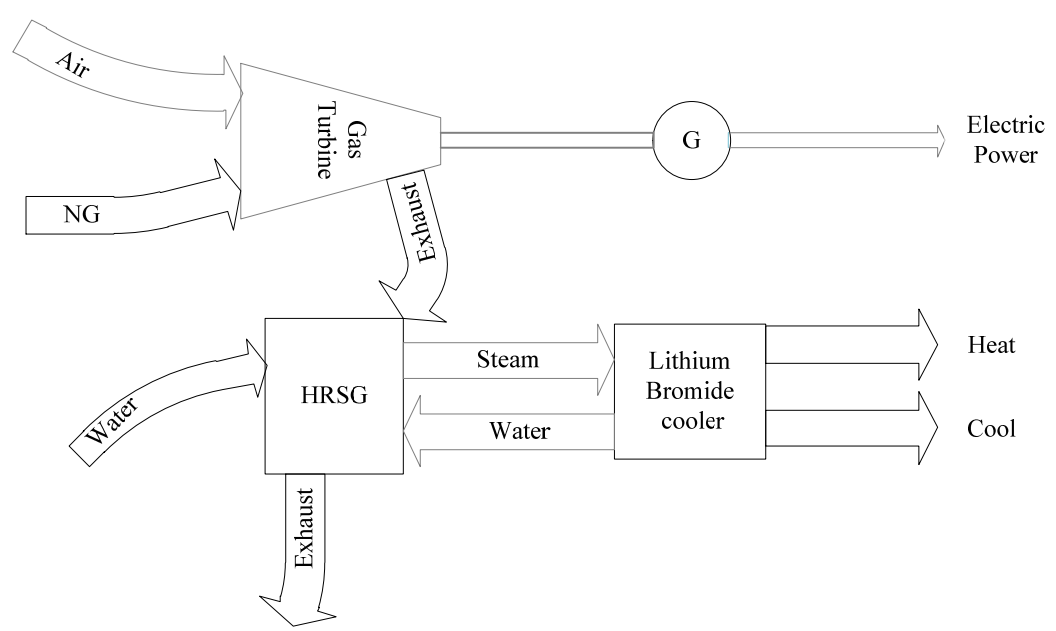

Figure 1. Flowing path working fluids in a CCHP energy system.

\subsection{Enthalpy Calculation}

2.2.1. Calculation of Exhaust Enthalpy in Gas Turbine

The gas turbine and its running parameters are listed in Table 1.

Table 1. Parameters of the gas turbine.

\begin{tabular}{cccc}
\hline Names & Values or Definitions & Names & Values or Definitions \\
\hline Type & LM1800e DLE ${ }^{\mathrm{TM}}$ & $i$ & Dollar exchange rate \\
\hline Capacity $P_{t}(\mathrm{MW})$ & 16.6 & $Q_{t u r-w}(\mathrm{KJ} / \mathrm{S})$ & $\begin{array}{c}\text { Heat emitted from the } \\
\text { gas turbine }\end{array}$ \\
\hline $\begin{array}{c}\text { Heat efficiency } \alpha \\
(\mathrm{KJ} / \mathrm{kWh})\end{array}$ & 10,525 & Heat of per unit $\mathrm{kWh}(\mathrm{KJ})$ & 3600 \\
\hline $\begin{array}{c}\text { Gas consumption per hour } \\
V_{\text {gas }}\left(\mathrm{M}^{3} / \mathrm{H}\right)\end{array}$ & 4992 & Price (Thousand yuan) & 5279 \\
\hline $\begin{array}{c}\text { Heating value of natural } \\
\text { gas per } \mathrm{m}^{3}(\mathrm{KJ})\end{array}$ & 35,000 & Annual power degradation & $1 \%$ \\
\hline Heat of exhaust $(\mathrm{KJ} / \mathrm{S})$ & 33,938 & Added value of equipment & $17 \%$ \\
\hline
\end{tabular}

Based on related literature [32] and the price fitting equation of a gas turbine (1), its price can be estimated; heat emission from the gas turbine per second can be calculated by Equations (2) and (3) is used for calculating gas consumption per hour:

$$
\begin{gathered}
C_{t}=(i+2.49) \times\left(20.42+0.033 P_{t}\right) \\
Q_{t u r-w}=V_{g a s} \times Q_{g a s} \times\left(1-\frac{\alpha}{Q_{g a s}}\right) / 3600 \\
V_{g a s}=\frac{\alpha}{Q_{g a s}}
\end{gathered}
$$

\subsubsection{Enthalpy Calculation of the Heat Recovery Boiler}

Considering the position of the CCHP system, the non-complementary type of heat recovery boiler was adopted in this study. If there are cases of insufficient power in heat and cold supply within the range of CCHP energy system, the heat and cold will be compensated on the user side. 
In the process of exhaust emission of the gas turbine through the exhaust port of the heat recovery boiler, the heat in the backwater and the efficiency of heat recovery boiler under different steam supply environments are taken into consideration. Then the energy output is calculated based on the energy balance The symbols and corresponding meanings are shown in Table 2.

Table 2. Symbols in the equation of the heat recovery boiler.

\begin{tabular}{clll}
\hline Symbols & Definition & Symbols & Definition \\
\hline$Q_{h r s-i n}$ & Heating input of heat recovery boiler & $M_{w c-i n}$ & Return water mass in cooling period \\
\hline$\beta_{h}$ & $\begin{array}{l}\text { Efficiency of heat recovery boiler in } \\
\text { heating period }\end{array}$ & $\gamma_{w s-o u t}$ & $\begin{array}{l}\text { Steam specific enthalpy of heat } \\
\text { recovery boiler in the rated conditions }\end{array}$ \\
\hline$\beta_{c}$ & $\begin{array}{l}\text { Efficiency of heat recovery boiler in } \\
\text { cooling period }\end{array}$ & $M_{w h s-o u t}$ & $\begin{array}{l}\text { Saturated steam mass in heating } \\
\text { period }\end{array}$ \\
\hline$M_{w h-i n}$ & Return water mass in heating period & $T_{w c-i n}$ & $\begin{array}{l}\text { Return water temperature in cooling } \\
\text { period }\end{array}$ \\
\hline$T_{w h-i n}$ & $\begin{array}{l}\text { Return water temperature in heating } \\
\text { period }\end{array}$ & $M_{w c s-o u t}$ & $\begin{array}{l}\text { Saturated steam mass in cooling } \\
\text { period }\end{array}$ \\
\hline
\end{tabular}

The enthalpy exchange equations of the process are:

$$
\begin{aligned}
& \text { Heating period: } Q_{h r s g-i n} \times \beta_{h}+M_{w h-i n} \times T_{w h-i n}=\gamma_{w s-o u t} \times M_{w h s-o u t} \\
& \text { Cooling period: } Q_{h r s-i n} \times \beta_{c}+M_{w c-i n} \times T_{w c-i n}=\gamma_{w s-o u t} \times M_{w c s-o u t}
\end{aligned}
$$

Without taking the backwater loss into consideration, the following can be obtained based on conservation of mass:

$$
\begin{aligned}
& M_{w h-i n}=M_{w h s-o u t} \\
& M_{w c-i n}=M_{w c s-o u t}
\end{aligned}
$$

Considering the differences in temperature environment in the heating and cooling period, in supplying heat, the efficiency of the heat recovery boiler is set as $85 \%$ and efficiency of the boiler in the cooling period is set as $80 \%$. The heat exchange parameters of the heat recovery boiler are shown in Table 3.

Table 3. Parameters of heat recovery boiler.

\begin{tabular}{ccccc}
\hline \multicolumn{2}{c}{ Exhaust Exchange End of Gas Turbine } & \multicolumn{2}{c}{ Output End of Steam } \\
\hline $\begin{array}{c}\text { Boiler heat input per unit time }(\mathrm{KJ} / \mathrm{S}) \\
\begin{array}{c}\text { Efficiency of heat recovery boiler in summertime } \\
\text { (Cooling period) }\end{array}\end{array}$ & 33,938 & Entering water temperature (summertime) $\left({ }^{\circ} \mathrm{C}\right)$ & 70 \\
\hline $\begin{array}{c}\text { Efficiency of heat recovery boiler in wintertime } \\
\text { (Heating period) }\end{array}$ & 0.8 & Entering water temperature (wintertime) $\left({ }^{\circ} \mathrm{C}\right)$ & 60 \\
\hline $\begin{array}{c}\text { Steam heat output (Cooling period) } \\
\text { Steam heat output (Heating period) }\end{array}$ & 27,150 & Heat capacity of water $\left(\mathrm{KJ} / \mathrm{KG}{ }^{*} \mathrm{C}\right)$ & 4.2 \\
\hline Rated power of heat recovery boiler $(\mathrm{kW})$ & 30,000 & Specific enthalpy of saturated steam $(\mathrm{KJ} / \mathrm{KG})$ & 2872 \\
\hline Price of heat recovery boiler (ten thousand yuan) & 200 & Mass of steam output $\mathrm{T} / \mathrm{H}(\mathrm{Cooling}$ period) & 38 \\
\hline & & Mass of steam output $\mathrm{T} / \mathrm{H}$ (Heating period) & 39.6 \\
\hline
\end{tabular}

Note: The data are calibrated based on the parameters of typical products and field survey data, and the output mass is calculated by the above energy output. 


\subsubsection{Calculation of Lithium-Bromide Heat-Cooler}

The double-effect steam-type lithium bromide refrigerator was adopted in this paper. The symbols and parameters in the equations are shown in Tables 4 and 5.

Table 4. Definition of the symbols in lithium bromide formula.

\begin{tabular}{|c|c|c|c|}
\hline Symbols & Definition & Symbols & Definition \\
\hline$M_{b r-h-o u t}$ & $\begin{array}{l}\text { Mass of lithium bromide backwater in } \\
\text { heating period }\end{array}$ & $\delta$ & Specific heat capacity of liquid water \\
\hline$Q_{b r-h-i n}$ & $\begin{array}{l}\text { Heat input in the lithium-bromide } \\
\text { heat-cooler in heating period }\end{array}$ & $Q_{b r-c-i n}$ & $\begin{array}{l}\text { Heat input in the lithium-bromide } \\
\text { heat-cooler in cooling period }\end{array}$ \\
\hline$M_{b r-c-o u t}$ & $\begin{array}{l}\text { Backwater mass of lithium bromide } \\
\text { refrigerator in cooling period }\end{array}$ & $C O P_{b r-c}$ & $\begin{array}{l}\text { Coefficient of performance of } \\
\text { lithium-bromide heat-cooler }\end{array}$ \\
\hline$C O P_{b r-h}$ & $\begin{array}{l}\text { Heating coefficient of } \\
\text { lithium-bromide heat-cooler }\end{array}$ & $\theta$ & Pipeline efficiency \\
\hline$\mu$ & Ratio of consumed energy & $C O P_{e h}$ & $\begin{array}{l}\text { Heating coefficient of electric } \\
\text { compressor }\end{array}$ \\
\hline$C O P_{e c}$ & $\begin{array}{l}\text { Coefficient of performance of electric } \\
\text { compressor }\end{array}$ & $P_{c}$ & Cooling power sent to the user side \\
\hline$P_{h}$ & Heating power sent to the user side & $P_{\text {in }}$ & $\begin{array}{l}\text { Power sent to the lithium-bromide } \\
\text { heat-cooler }\end{array}$ \\
\hline$C_{b r}$ & Price of lithium-bromide heat-cooler & $P_{b r}$ & $\begin{array}{l}\text { Output power of lithium-bromide } \\
\text { heat-cooler }\end{array}$ \\
\hline$\theta_{1}$ & $\begin{array}{l}\text { Change of return water temperature } \\
\text { in cooling period }\end{array}$ & $\theta_{2}$ & $\begin{array}{l}\text { Change of return water temperature } \\
\text { in heating period }\end{array}$ \\
\hline
\end{tabular}

Table 5. Operation parameters of lithium-bromide heat-cooler.

\begin{tabular}{|c|c|c|c|}
\hline Parameters & Values & Parameters & Values \\
\hline Heat input (in cooling period) & 30,246 & Exchanged power KW (in heating period) & 31,621 \\
\hline heat input (in heating period) & 31,621 & Exchanged power KW (in cooling period) & 30,246 \\
\hline Pressure of steam input (MP) & 0.6 & Cooling COP of lithium bromide & 1.33 \\
\hline Temperature of steam input $\left({ }^{\circ} \mathrm{C}\right)$ & 210 & Heating COP of lithium bromide & 0.93 \\
\hline $\begin{array}{l}\text { Specific enthalpy of saturated steam under the } \\
\text { condition }(\mathrm{KJ} / \mathrm{kg})\end{array}$ & 2872 & Cooling COP of electric compressor & 4.5 \\
\hline Steam input mass (in cooling period) & 38 & Heating COP of electric compressor & 3 \\
\hline Steam input mass (in heating period) & 40 & Pipeline efficiency & 0.98 \\
\hline Water discharge temperature in summertime $\left({ }^{\circ} \mathrm{C}\right)$ & 90 & Cooling power to users $(\mathrm{kW})$ & 39,422 \\
\hline Mass of discharged water in summertime $\left({ }^{\circ} \mathrm{C}\right)$ & 38 & Heating power to users $(\mathrm{kW})$ & 28,820 \\
\hline Unit temperature in wintertime $\left({ }^{\circ} \mathrm{C}\right)$ & 70 & $\begin{array}{l}\text { Price of lithium bromide heat-cooler unit } \\
\text { (ten thousand yuan) }\end{array}$ & 3360 \\
\hline Mass of discharged water in wintertime $\left({ }^{\circ} \mathrm{C}\right)$ & 40 & & \\
\hline
\end{tabular}

Heat balance of lithium bromide unit in heating period:

$$
\gamma_{w s-o u t} \times M_{w h s-o u t}+M_{b r-h-o u t} \times \delta \times \theta_{1}=Q_{b r-h-i n}
$$

Heat balance of lithium bromide unit in cooling period:

$$
\gamma_{w s-o u t} \times M_{w c s-o u t}+M_{b r-c-o u t} \times \delta \times \theta_{2}=Q_{b r-c-i n}
$$




$$
\begin{aligned}
& M_{\text {whs-out }}=M_{b r-h-o u t} \\
& M_{\text {wcs-out }}=M_{b r-c-o u t}
\end{aligned}
$$

The power transmitted to user side can be calculated by the COP value of the lithium-bromide heat-cooler as follows:

$$
\begin{aligned}
& P_{c}=P_{i n} \times \mathrm{COP}_{b r-c} \times \theta \times \mu \\
& P_{h}=P_{i n} \times \mathrm{COP}_{b r-h} \times \theta \times \mu
\end{aligned}
$$

Electricity-driven refrigeration and heating power can be obtained as follows after conversion:

$$
\begin{gathered}
P_{d-c}=P_{c} / \mathrm{COP}_{e c} \\
P_{d-h}=P_{h} / \mathrm{COP}_{e h}
\end{gathered}
$$

Fitting formula of the lithium bromide refrigerator:

$$
C_{b r}=0.112 \times P_{b r}
$$

According to the research results by health departments at home and abroad, when the human body has suitable clothing, warm and quiet, it feels comfortable when the indoor temperature is maintained at $20^{\circ} \mathrm{C}$, and it does not feel cold at $18{ }^{\circ} \mathrm{C}$, but it feels obviously cold at $15^{\circ} \mathrm{C}$. According to the requirements of the current Indoor Air Quality Standard (GB/T 18883), the indoor temperature range of main rooms of civil buildings should be maintained at $16-24{ }^{\circ} \mathrm{C}$. In Beijing, for example, the heating period is definite, and cooling is supplied when the monthly average temperature is higher than $24^{\circ} \mathrm{C}$. The cold energy is then supplied and consumed. Based on the requirements above, the total required time for cold and heat energy is 214 days, namely $5136 \mathrm{~h}$.

\section{Two Evaluation Methods for CCHP Energy System and Their Comparison}

Two methods for the evaluation of the CCHP energy system are employed in this study, and a mutual verification is conducted on them based on the respective results. The first method is energy-equivalent-based LCOE, which is commonly used worldwide. By converting the electrical energy output produced by the system and heating and cooling energy produced in the CCHP energy system to equivalent electricity quantities based on the COP efficiency of electricity-driven refrigeration and heating, the equivalent kilowatt cost can be calculated based on the definition of LCOE. The second method coverts the heating and cooling energy produced by the CCHP energy system into income based on the local heating and cooling prices to compensate for some costs, and the total consumption after taking out the income of heating and cooling is regarded as total cost to calculate the LCOE of produced pure electricity. The first method (energy equivalent) is suitable for regions without clear heating and cooling prices. Since the COP coefficient of the electric compressor may vary in different systems, this method may not produce precise results. While the second method (economic value equivalent) is applicable in regions with definite heating and cooling prices, because the heating and cooling income compensate for some costs. The LCOE of pure electricity in the region calculated in this method is more accurate.

\subsection{LCOE Model}

Since the output of the CCHP energy system is not restricted to electric energy, the definition of LCOE from NREL [30] is adopted in this paper for calculation. Symbols and their meanings in the LCOE calculation equation and some parameters are shown in Tables 6 and 7. 
Table 6. Symbols and their meanings in the LCOE calculation equation.

\begin{tabular}{cccc}
\hline Symbols & Meaning & Symbols & Meaning \\
\hline$C O S T_{n}$ & The expenses of the nth year & $E_{n}$ & Energy output of the nth year \\
$r$ & Discount rate & $E G_{n}$ & Electric energy output of the nth year \\
$E H_{n}$ & Heat energy output of the nth year & $E C_{n}$ & Cooling output of the nth year \\
$P_{t}$ & Rated power of gas turbine & $T_{e}$ & Annual utilization hours \\
$S$ & Decay rate of electricity generation & $P_{d-h}$ & Heating equivalent electric power \\
$P_{d-c}$ & Cooling equivalent electric power & $T_{n h}$ & Heating period \\
$T_{n c}$ & Cooling period & $U_{n}$ & Ratio of consumed heating and cooling energy \\
$O P E N_{n}$ & Operation expenses & $T A X_{n}$ & Taxation \\
$C A P X_{n}$ & Depreciation for fixed assets of the year & $N G_{n}$ & Fuel cost \\
$H C_{n}$ & Labor cost & $C I_{n}$ & Loan interest \\
$C$ & Gross value of assets & $I$ & Premium rate \\
$F I X$ & Maintenance rate & $S U$ & Income tax \\
$Z E$ & Added value & $F A$ & Housing property tax \\
$T U$ & Land-use fees (rent) & $C H$ & Urban maintenance and construction tax \\
$E D$ & Additional education tax & $W$ & Number of employees \\
$W S$ & Annual salary of employees & $f$ & Welfare and labor Insurance coefficient \\
$p$ & Annual rate of growth of staff salaries & $O_{n}$ & Loan to be repaid for the same year \\
$j$ & Loan interest rate & $T_{c}$ & Yearly duration of cooling \\
$T_{h}$ & Yearly duration of heating & $M_{c}$ & Price of cooling \\
$M_{h}$ & Price of heating & & \\
\hline
\end{tabular}

Table 7. Some parameter values in the equations.

\begin{tabular}{|c|c|c|c|}
\hline Cost Categories & Value & Cost Categories & Value \\
\hline Premium rate & $0.25 \%$ & Number of employees & 20 \\
\hline Discount rate & $8 \%$ & Welfare and labor Insurance coefficient & $60 \%$ \\
\hline Cooling price (yuan/kWh) & $0.3[33]$ & Annual rate of growth of staff salaries & $6 \%$ \\
\hline Heating price (yuan/kWh) & $0.2[33]$ & Heating and cooling energy consumption ratio & $40-100 \%$ \\
\hline Design and installation expenses & $10 \%[34]$ & Heating value of natural gas per cubic meter & $35,000 \mathrm{KJ} / \mathrm{M}^{3}$ \\
\hline Period of depreciation (year) & $20[34]$ & Duration of cooling $(\mathrm{H})$ & 2208 \\
\hline Income tax $(\%)$ & $25 \%$ & Heat per kilowatt & $3600 \mathrm{KJ}$ \\
\hline Added-value tax & $17 \%$ & Rate of bank loans (\%) & $6 \%$ \\
\hline Housing property tax (\%) & $1 \%$ & Bank loan period (year) & 20 \\
\hline Deduction proportion of Housing property tax (\%) & $30 \%$ & After-tax internal rate of return & $8 \%$ \\
\hline Urban maintenance and construction tax (\%) & $5 \%$ & Annual utilization hours of distributed natural gas & 5000 \\
\hline
\end{tabular}

Note: The tax rates are set according to the government regulations, and other data is set by actual case study.

Based on the definition of LCOE and the characteristics of the CCHP energy system, the following equation can be obtained:

$$
\mathrm{LCOE}=\sum_{n=1}^{N} \frac{\operatorname{COST}_{n}}{(1+r)^{n}} / \sum_{n=1}^{N} \frac{E_{n}}{(1+r)^{n}}
$$

The equations of the first method:

$$
\begin{gathered}
E_{n}=E G_{n}+E H_{n}+E C_{n} \\
E G_{n}=P_{t} \times T_{e} \times(1-S)^{n-1} \\
E H_{n}=P_{d-h} \times T_{n h} \times U_{n} \\
E C_{n}=P_{d-c} \times T_{n c} \times U_{n} \\
\operatorname{COST}_{n}=\mathrm{OPEN}_{n}+\mathrm{TAX}_{n}+\mathrm{CAPX}_{n}+N G_{n}+H C_{n}+C I_{n} \\
\mathrm{OPEN}_{n}=\mathrm{C} \times(I+\mathrm{FIX}) \\
\mathrm{TAX}_{n}=\mathrm{SU}_{n}+\mathrm{ZE}_{n}+\mathrm{FA} A_{n}+\mathrm{TU} U_{n}+C H_{n}+E D_{n} \\
N G_{n}=N G P_{n} \times V_{g a s} \times T_{e}
\end{gathered}
$$




$$
\begin{gathered}
H C_{n}=W \times W S \times(1+f) \times(1+p)^{n} \\
C I_{n}=O_{n} \times j
\end{gathered}
$$

The equations of the second method:

$$
E_{n}=E G_{n}
$$

$$
\mathrm{COST}_{n}=\mathrm{OPEN}_{n}+\mathrm{TAX}_{n}+\mathrm{CAPX}_{n}+N G_{n}+H C_{n}+C I_{n}-P_{c} \times T_{c} \times M_{c}-P_{h} \times T_{h} \times M_{h}
$$

\subsection{Setting of Baseline Situation}

According to the related studies, and the current domestic policies and economic environment [35], the parameter settings of the baseline situation and range are shown in Table 8, in which the parameters for the ratio of heating and cooling durations are set according to the durations of heating and cooling air-conditioning in Beijing, and the duration of heating and cooling energy supply is 214 days, including $2208 \mathrm{~h}$ of cooling supply and $2928 \mathrm{~h}$ of heating supply. The total duration is $5126 \mathrm{~h}$ since the heating and cooling energy are supplied on an all-day basis. According to different power grids, the wheeling cost is about 40 yuan/MWh [36], which only takes up a small proportion in costs, thus it is not included in cost calculation.

Table 8. Parameter settings under baseline situation.

\begin{tabular}{ccc}
\hline Parameters & Baseline Situation & Varying Range (Change Gradient) \\
\hline Price of natural gas $\left(\right.$ yuan $\left./ \mathrm{m}^{3}\right)$ & 2.6 & 0.1 \\
Consumed electricity & $90 \%$ & $2 \%$ \\
Duration of cooling $(\mathrm{H})$ & 2208 & 120 \\
Duration of heating $(\mathrm{H})$ & 2928 & 120 \\
Heating and cooling energy consumption ratio & $90 \%$ & $2 \%$ \\
Bank loan ratio & 0 & $10 \%$ \\
\hline
\end{tabular}

\subsection{Calculation Results}

According to the equations above, the cost composition of LCOE of the first and second methods under baseline situation can be calculated and shown in Figure 2.

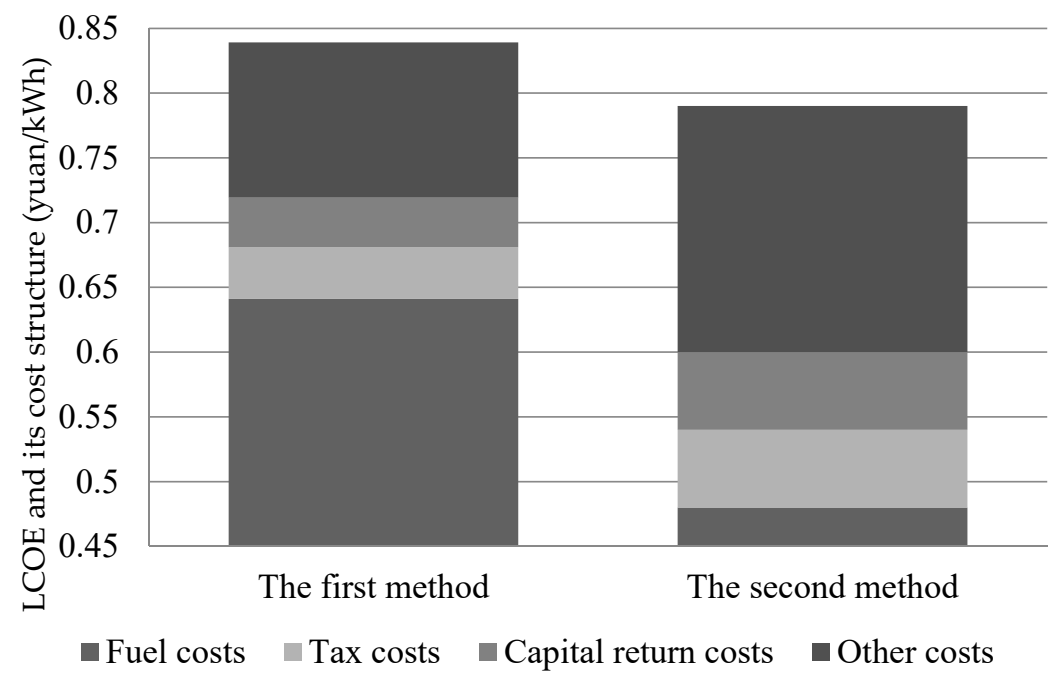

Figure 2. Cost structure. 
The results show that there is little difference between the LCOE by the two methods, and that under current policy conditions, the price of per unit exergy of the CCHP energy system in the regions studied in this paper is about 0.8 yuan. According to the first method, fuel costs account for about $75 \%$ of the total cost. However, in the second method, since the profits from heating and cooling are converted to fuel costs, the fuel costs decline significantly decline, accounting for $60 \%$ of the total cost. In order to mark the regions that are suitable for developing the CCHP energy system in China, based on the first method, the difference between the commercial tariff in the capital city of each province and LCOE for the 16.6 MW unit (yuan $/ \mathrm{kWh}$ ) was calculated in relation to the climate characteristics, demand intensity in heating and cooling energy, fuel price and commercial tariff (see Table 9). According to the results, the status of the CCHP energy systems in different provinces varies: there are provinces suffering from huge loss, or slight loss, while some other provinces retain slight profits, or rich profits (Figure 3).

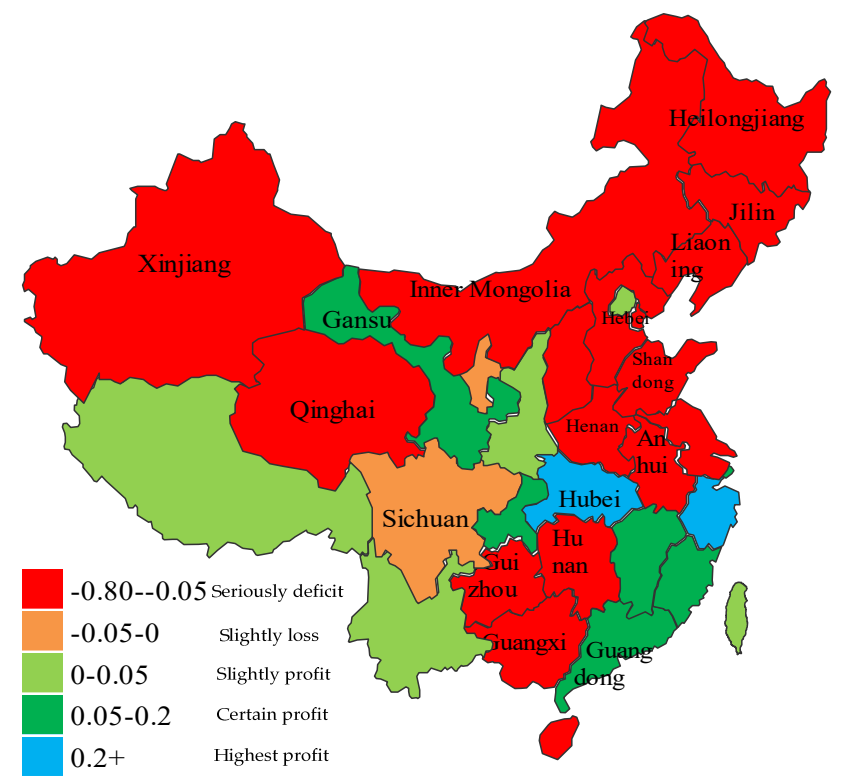

Figure 3. National profitability map.

The CCHP energy system in most areas is scarcely profitable or worse. The provinces that make profits and high profits are mainly economically developed regions that have more reasonable natural gas prices, and strong demands in heating and cooling energy. In order to further identify the factors that have greater impacts on LCOE, a sensitivity analysis is done on the factors that may affect costs in this paper.

The values in Figure 3 are the differences between the local commercial electricity prices and the corresponding LCOEs calculated in this paper. The red area is the seriously deficit area; the orange is the slightly loss area; the light green is the slightly profitable area; the green is the certain profitable area, and the blue is the highest profitable area. 
Table 9. Provincial parameters for calculation.

\begin{tabular}{|c|c|c|c|c|c|c|c|c|c|c|c|}
\hline Regions & Provinces & $\begin{array}{l}\text { Duration of } \\
\text { Cooling }(\mathrm{H})\end{array}$ & $\begin{array}{l}\text { Duration of } \\
\text { Heating }(\mathrm{H})\end{array}$ & $\begin{array}{c}\text { Price of Natural } \\
\text { Gas for Power } \\
\text { Generation (yuan) }\end{array}$ & $\begin{array}{l}\text { Commercial } \\
\text { Tariff (yuan) }\end{array}$ & Regions & Provinces & $\begin{array}{l}\text { Duration of } \\
\text { Cooling (H) }\end{array}$ & $\begin{array}{l}\text { Duration of } \\
\text { Heating }(\mathrm{H})\end{array}$ & $\begin{array}{c}\text { Price of Natural } \\
\text { Gas for Power } \\
\text { Generation (yuan) }\end{array}$ & $\begin{array}{l}\text { Commercial } \\
\text { Tariff (yuan) }\end{array}$ \\
\hline \multirow{7}{*}{ Bitter cold regions } & Xinjiang & \multirow{7}{*}{720} & \multirow{7}{*}{4080} & 2.39 & 0.59 & \multirow{10}{*}{$\begin{array}{l}\text { Hot summer-cold } \\
\text { winter regions }\end{array}$} & Henan & \multirow{10}{*}{4416} & \multirow{10}{*}{2136} & 2.90 & 0.77 \\
\hline & Inner Mongolia & & & 2.67 & 0.68 & & Jiangsu & & & 3.25 & 0.88 \\
\hline & Heilongjiang & & & 3.85 & 0.90 & & Sichuan & & & 3.00 & 0.86 \\
\hline & Qinghai & & & 1.81 & 0.60 & & Hunan & & & 3.10 & 0.83 \\
\hline & Jilin & & & 3.20 & 0.90 & & Jiangxi & & & 3.15 & 0.98 \\
\hline & Shaanxi & & & 2.46 & 0.87 & & Fujian & & & 2.37 & 0.81 \\
\hline & Liaoning & & & 3.18 & 0.87 & & Anhui & & & 3.30 & 0.88 \\
\hline \multirow{7}{*}{ Cold regions } & Gansu & \multirow{7}{*}{2208} & \multirow{7}{*}{2928} & 1.99 & 0.80 & & Zhejiang & & & 2.29 & 1.15 \\
\hline & Shanxi & & & 3.20 & 0.79 & & Chongqing & & & 2.14 & 0.85 \\
\hline & Hebei & & & 2.95 & 0.75 & & Shanghai & & & 2.50 & 0.96 \\
\hline & Shandong & & & 3.50 & 0.76 & \multirow{3}{*}{ Mild regions } & Yunnan & \multirow{3}{*}{2208} & & & \\
\hline & Tianjin & & & 2.77 & 0.81 & & Guizhou & & & 3.59 & 0.72 \\
\hline & Beijing & & & 2.67 & 0.87 & & Guangxi & & & 4.18 & 0.84 \\
\hline & Ningxia & & & 2.06 & 0.69 & \multirow{2}{*}{$\begin{array}{l}\text { Hot summer-warm } \\
\text { winter regions }\end{array}$} & Hainan & \multirow{2}{*}{7200} & & 3.96 & 0.90 \\
\hline $\begin{array}{l}\text { Hot summer-cold } \\
\text { winter regions }\end{array}$ & Hubei & 4416 & 2136 & 2.37 & 0.98 & & Guangdong & & & 2.58 & 0.93 \\
\hline
\end{tabular}




\section{Sensitivity Analysis}

The sensitivity analysis results show that, the more the usable exergy produced by the CCHP system is, the lower the natural gas price and the ratio of self-owned capital will be, and the higher competitiveness of the LCOE price will be. First, the change in fuel price has great impact on the LCOE of the system, because the fuel cost accounts for about $75 \%$ of the total cost. With the rise in natural gas price, the LCOE cost will also increase along with the rise of natural gas price (Figure 4). When the fuel price is equal to the natural gas price of gas stations $\left(2 \mathrm{yuan} / \mathrm{m}^{3}\right)$, the LCOE is about $0.65 \mathrm{yuan} / \mathrm{kWh}$. In this case, the economical efficiency of the system is relatively high.

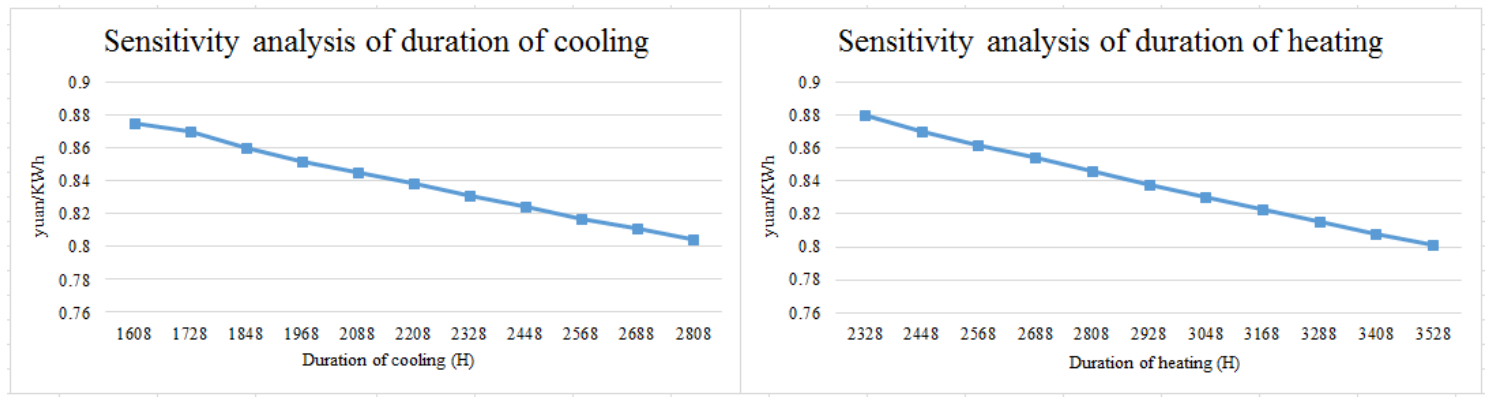

Figure 4. Diagram of sensitivity analysis.

Second, the influence of demand intensity in heating and cooling energy on the LCOE is only second to the natural gas price, and the power output and consumption in the energy system also affects the LCOE. In the energy system structure studied in this paper, when the heating and cooling consumption intensity determined by the climate and the ratio of heating and cooling consumption expands in terms of time and percentage, the LCOE of the energy system has a descending trend (Figures 4 and 5). When the consumption of heating and cooling energy increases, the unit cost decreases by 0.1 yuan $/ \mathrm{kWh}$. The reason for the significant decline lies in that, with the increase of the utilization rate of heating and cooling energy in the CCHP system, the output of exergy increases. Therefore, when the cost is fixed, the price of per unit exergy also decreases. It shows that the CCHP energy system has good economical efficiency in regions that have higher demands on heating and cooling energy. When on-grid power ratio decreases by $20 \%$, the kilowatt cost may increase by 0.1 yuan (Figure 5). Therefore, in planning the CCHP energy system, local climate and the rigid demand on heating and cooling energy should be taken into account. Meanwhile, local economic status should also be considered. Whether the heating and cooling energy output can be consumed is another key factor for the LCOE of the system. Besides, favorable policies for on-grid power also influence the competitiveness of the system.

Lastly, another factor in the LCOE of the CCHP energy system is the ratio of bank loans. The change in bank loan ratio has impact on the LCOE, and the sensitivity of bank loan ratio (or self-owned capital) is very low (Figure 5).

The sensitivity analysis of the above factors shows that, the factors in the economical efficiency of the CCHP energy system mainly include the natural gas price and the final exergy consumption. Based on the quantitative analysis of these factors, the authors propose the main factors that influence the large-scale advancement of the CCHP energy system and the corresponding policy suggestions. 


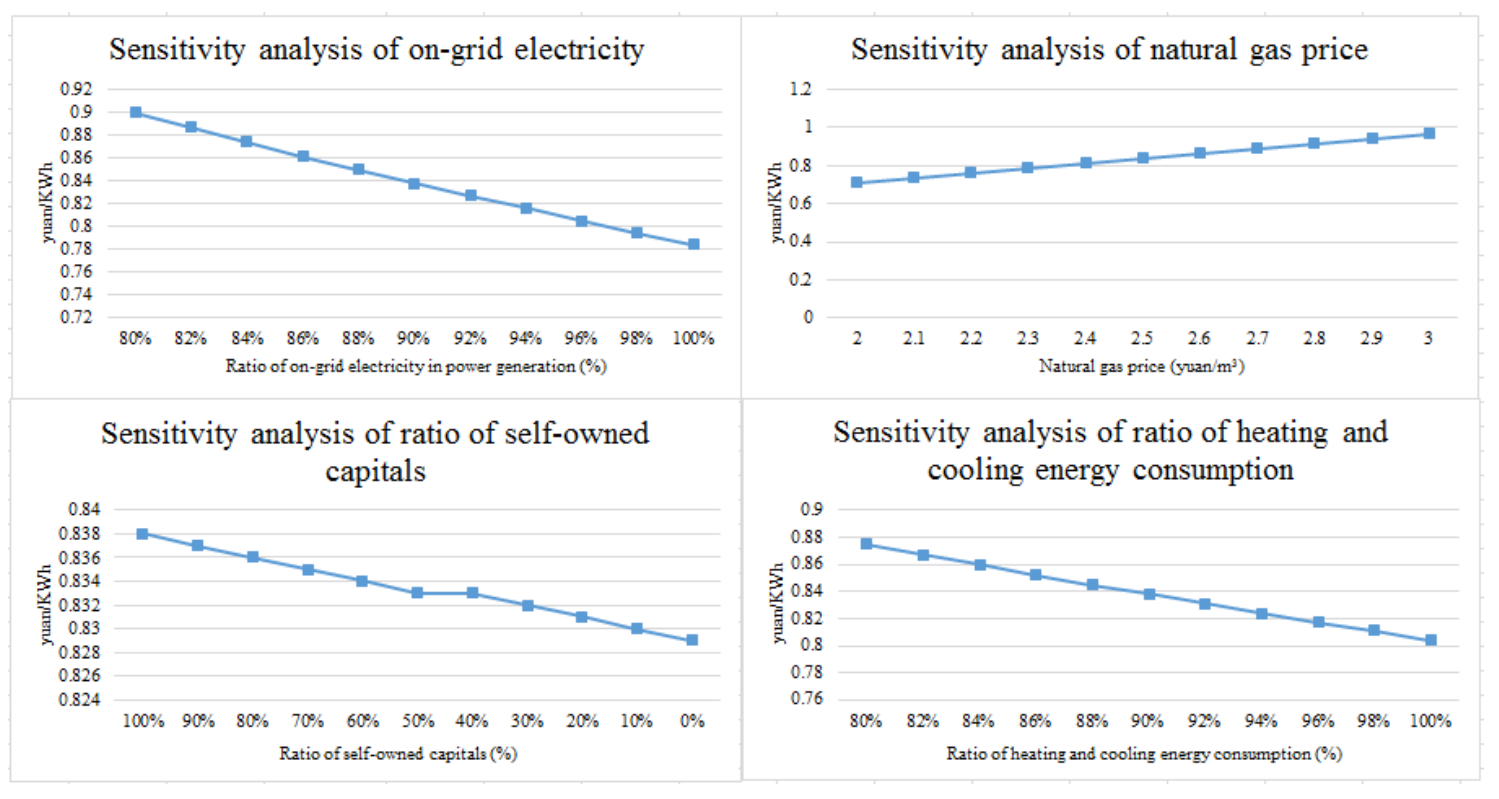

Figure 5. Sensitivity analysis diagrams.

\section{Conclusions and Policy Suggestions}

\subsection{Conclusions}

Two methods are employed in this paper to calculate the LCOE for evaluating the economical efficiency of CCHP energy systems. According to the first method based upon energy equivalent, fuel costs account for about $75 \%$ of the total cost. In the second method based upon economic value equivalent, the profits from heating and cooling are converted to fuel costs, resulting in a significant decline of fuel costs ( $60 \%$ of the total cost). Then the heating and cooling parameters of gas turbine exhaust, heat recovery boiler, lithium-bromide heat-cooler and commercial tariff of provincial capitals were set as benchmarks based on geographic division among provinces, and the economical efficiency of combined cooling heating and power system in each province was evaluated. From the national profitability map and economic analysis, it shows that the CCHP energy system has economical efficiency only under good operation environment conditions, and it possesses great potential in the central and eastern part of China where market demand and commercial electricity tariffs are higher. In the condition of the internal rate of return of $8 \%$, Guangdong, Chongqing, Hubei, Zhejiang and other provinces still have a high competitive edge. Further reforms in the natural gas market and electricity retailing have laid a foundation for the improvement of the economic efficiency of CCHP energy systems, and their positioning in the entire energy system will be gradually clarified. The economical efficiency of CCHP systems is greatly influenced by the quantity of exergy consumption, and it has poor economical efficiency in areas with temperate climates.

A sensitivity analysis was conducted on key influencing factors, including fuel cost, demand intensity in heating and cooling energy, and bank loans ratio. It shows that the fuel cost has a decisive influence on the economical efficiency of the CCHP energy system. The main reason is that the fuel costs account for about $75 \%$ of the total cost. With the rise in natural gas prices, the unit's costs must rise. Then, the influence of demand intensity in heating and cooling energy on LCOE is only second to fuel cost. When the consumption of heating and cooling energy increases, the unit cost decreases by 0.1 yuan $/ \mathrm{kWh}$, and when on-grid power ratio decreases by $20 \%$, the cost may increase by 0.1 yuan $/ \mathrm{kWh}$. The paper also provides the policy suggestions of setting a reasonable natural gas price, distributed energy output and energy consumption policy to promote the CCHP system. 


\subsection{Policy Suggestions}

\subsubsection{Improve the Development Mechanism for the CCHP Energy System}

The positioning of the CCHP energy system in the energy structure should be determined as soon as possible, and the energy structure should be optimized for the development of non-coal energy systems. CCHP energy systems are very sensitive to the operating environment, thus it is necessary to determine its status in relation to the regional resource environment, and formulate promotion policies according to environmental differences.

\subsubsection{Enhance Energy Supply and Consumption Market Reform}

(1) Electricity market. It is necessary to improve the pricing mechanism of the electricity market, and give full play to the characteristics of gas turbine generator sets, in order to achieve electricity output at peak time, and reduce the total cost of the system. Moreover, technological support should be provided for the on-grid electricity in CCHP systems and technology technological standards for grid-connection should be established as soon as possible.

(2) Natural gas market. Based on the analysis of the two different cost compositions, natural gas prices have a crucial impact on the economical efficiency of CCHP energy systems. However, the pricing of natural gas should not only consider the costs and profits, but also the social, energy-saving and environmental benefits for gas users. Thus different ways of calculation for gas transmission and distribution prices can reduce the fuel costs of CCHP energy systems, and promote the development of CCHP energy systems.

(3) Heating and cooling supply market. The consumption quantity of heating and cooling energy demonstrates the ability of changing anergy into exergy. The thermal efficiency of the system lies in the output and consumption of heating and cooling energy. According to the different climates of different regions and the results of the second method, the form of subsidies can be diversified to fully improve the competitiveness of the CCHP energy systems in each region.

Acknowledgments: The authors would like to thank the anonymous reviewers for their useful comments and suggestions. The work reported in the paper is funded by the National Natural Science Foundation of China (71673085) and the Beijing Municipal Social Science Foundation (16YJB027) and supported by Program for the Philosophy and Social Sciences Research of Higher Learning Institutions of Shanxi (2017251) and Youth Research Foundation of Shanxi University of Finance and Economics (QN-2017008).

Author Contributions: Yan Xu and Jiahai Yuan conducted the analysis and drafted the paper; Wenyu Li collected the data for analysis.

Conflicts of Interest: The authors declare no conflict of interest.

\section{References}

1. Zhao, C.H.; Zhang, H.N.; Zhang, X.P.; Yuan, J.H. Economic research on centralized gas power generation projects. Int. Petrol. Econ. 2016, 24, 57-63. (In Chinese)

2. Ebrahimi, M.; Keshavarz, A. CCHP the Future. Comb. Cool. Heat. Power 2015, 197-200.

3. Caliano, M.; Bianco, N.; Graditi, G.; Mongibello, L. Analysis of a biomass-fired CCHP system considering different design configurations. Energy Procedia 2017, 105, 1683-1691. [CrossRef]

4. Uris, M.; Linares, J.I.; Arenas, E. Feasibility assessment of an Organic Rankine Cycle (ORC) cogeneration plant (CHP/CCHP) fueled by biomass for a district network in mainland Spain. Energy 2017, 133, 969-985. [CrossRef]

5. Li, G.Q.; Zhang, R.F.; Jiang, T.; Chen, H.H.; Bai, L.Q.; Cui, H.T.; Li, X.J. Optimal dispatch strategy for integrated energy systems with CCHP and wind power. Appl. Energy 2017, 192, 408-419. [CrossRef]

6. Yousefi, H.; Ghodusinejad, M.H.; Kasaeian, A. Multi-objective optimal component sizing of a hybrid ICE + PV/T driven CCHP microgrid. Appl. Therm. Eng. 2017, 122, 126-138. [CrossRef]

7. Wang, Z.F.; Han, W.; Zhang, N.; Liu, M.; Jin, H.G. Proposal and assessment of a new CCHP system integrating gas turbine and heat-driven cooling/power cogeneration. Energy Convers. Manag. 2017, 144, 1-9. [CrossRef] 
8. Yuan, J.H.; Li, W.Y.; Zhang, X.P. Economic research on distributed gas CCHP system. Int. Petrol. Econ. 2016, 24, 61-68. (In Chinese)

9. Wang, L.; Lu, J.F.; Wang, W.; Ding, J. Feasibility analysis of CCHP system with thermal energy storage driven by micro turbine. Energy Procedia 2017, 105, 2396-2402. [CrossRef]

10. Xu, J.Z. The prospects for distributed power supply and CCHP. Energy Conserv. 2002, 3, 10-14. (In Chinese)

11. Gu, W.; Wu, Z.; Bo, R.; Liu, W.; Zhou, G.; Chen, W.J.; Wu, Z. Modeling, planning and optimal energy management of combined cooling, heating and power micro grid: A review. Int. J. Electr. Power Energy Syst. 2014, 54, 26-37. [CrossRef]

12. Xu, Q.H.; Peng, B. Synopsis of the 2012 APEC Distributed Energy Forum- Also covering development of natural gas distributed energy in China. Int. Petrol. Econ. 2013, 96-101. (In Chinese)

13. State Development Planning Commission, State Economic and Trade Commission, Ministry of Construction, State Environmental Protection Administration of China. Provisions on the Development of Combined Heat and Power Generation 2011. Available online: http:/ /www.nea.gov.cn/2011-11/22/c_131262611.htm (accessed on 20 October 2017).

14. Ministry of Housing and Urban-Rural Development. A Technical Regulation Document for the Development and Construction of CCHP; CJJ145-2010; Ministry of Housing and Urban-Rural Development: Beijing, China, 2010.

15. National Development and Reform Commission, National Energy Administration, Ministry of Housing and Urban-Rural Development. The Implementation Rules of Natural Gas Distributed Energy Demonstration Project 2014. Available online: http://www.china-gas.org.cn/tzgg/2014-10-31/786.html (accessed on 20 October 2017).

16. Wang, J.; Li, X.R.; Yang, H.M.; Chen, G. An Integration Scheme for DES/CCHP Coordinated with Power System. Autom. Electr. Power Syst. 2014, 38, 16-21. (In Chinese)

17. Zhang, C.; Liu, L.M.; Cheng, S.; Zheng, C.G. Performance evaluation of thermal power system based on the structure theory of thermoeconomic. Proc. CSEE 2005, 25, 108-113. (In Chinese)

18. Li, Y.H.; Li, G.S.; Yan, S.L. A general matrix equation of exergy Loss distribution in regenerative systems of fossil fired power sets. J. Power Eng. 2006, 26, 595-598. (In Chinese)

19. Zhang, C.; Wang, Y.; Zheng, C.G.; Lou, X.S. Exergy cost analysis of a coal fired power plant based on structural theory of thermoeconomics. Energy Conserv. Manag. 2006, 47, 817-843. [CrossRef]

20. Zhai, R.R.; Liu, H.T.; Li, C.; Zhao, M.M.; Yang, Y.P. Analysis of a solar-aided coal-fired power generation system based on thermo-economic structural theory. Energy 2016, 102, 375-387. [CrossRef]

21. Martinopoulos, G.; Papakostas, K.T.; Papadopoulos, A.M. Comparative Analysis of Various Heating Systems for Residential Buildings in Mediterranean climate. Energy Build. 2016, 124, 79-87. [CrossRef]

22. Biglia, A.; Caredda, F.V.; Fabrizio, E.; Filippi, M.; Mandas, N. Technical-economic feasibility of CHP systems in large hospitals through the Energy Hub method: The case of Cagliari AOB. Energy Build. 2017, 147, 101-112. [CrossRef]

23. Liu, X.J.; Li, J.; Qu, Y.; Chen, J.Q. Overview of Modeling of Combined Cooling Heating and Power System. Power Syst. Clean Energy 2012, 28, 63-68. (In Chinese)

24. Liao, M.Y. Economic Analysis of CCHP System Based Microgrid. Master's Thesis, South China University of Technology, Guangzhou, China, 2014. (In Chinese)

25. Hou, X.Y.; Liang, Y.H. Economic analysis on gas-fired building cooling heating and power systems. Heat. Vent. Air Cond. 2016, 46, 24-28. (In Chinese)

26. Abusoglu, A.; Sedeeq, M.S. Comparative exergoenvironmental analysis and assessment of various residential heating systems. Energy Build. 2013, 62, 268-277. [CrossRef]

27. Xiang, X.Y. Engineering Exergy Analysis Method; Petroleum Industry Press: Beijing, China, 1990. (In Chinese)

28. Yuan, J.H.; Na, C.N.; Xu, Y.; Zhao, C.H. Feed-In Tariff for Onshore Wind Power in China. Emerg. Mark. Financ. Trade 2016, 52, 1427-1437. [CrossRef]

29. Yuan, J.H.; Sun, S.H.; Zhang, W.H.; Xiong, M.P. The economy of distributed PV in China. Energy 2014, 78, 939-949. [CrossRef]

30. National Renewable Energy Laboratory. Simple Levelized Cost of Energy Calculator Documentation 2010. Available online: http:/ / www.nrel.gov/analysis/lcoe_documentation.html (accessed on 20 October 2017).

31. GE Power \& Water Aeroderivative Gas Turbines Report; Fast, Flexible Power Aeroderivative Product and Service Solutions; GE Power \& Water: Houston, TX, USA, 2011. 
32. Lin, Q.R. The Optimization and Operation Strategy Study of Combined Cooling Heating and Power System. Master's Thesis, Nanjing University of Science \& Technology, Nanjing, China, 2014. (In Chinese)

33. Wang, Z.M. Multiple Price Factors Influence the Gas DES. Power Gener. Air Cond. 2013, 34, 1-4. (In Chinese)

34. Feng, Z.B.; Jin, H.G. Technology of Gas Turbine Tri-generation (Cooling, Heating and Electric Power) System and Its Economic Analysis. J. Eng. Therm. Energy Power 2005, 20, 425-429. (In Chinese)

35. Ding, X.C.; Zhou, Y.H.; Wang, S.W. Method for Evaluating Economic Feasibility of Distributed Energy. Power Gener. Air Cond. 2015, 36, 1-5. (In Chinese)

36. Luo, Q.; Lu, L. Wheeling Price Calculating Method in the Price of Direct Power Transmission to Large Customers. Electr. Power Sci. Eng. 2008, 24, 38-41. (In Chinese)

(C) 2017 by the authors. Licensee MDPI, Basel, Switzerland. This article is an open access article distributed under the terms and conditions of the Creative Commons Attribution (CC BY) license (http://creativecommons.org/licenses/by/4.0/). 